\title{
BANK KELILING PEMBURU RENTE DAN INVOLUSI USAHA PEDAGANG PASAR
}

\author{
Rahoyo $^{1}$ \\ Rr. Lulus Prapti NSS ${ }^{2}$
}

Fakultas Ekonomi, Universitas Semarang

stefanus.rahoyo1970@gmail.com ${ }^{1}$

Diterima: Agustus 2019, Disetujui: September 2019, Dipublikasikan: Oktober 2019

\begin{abstract}
Rent seeking mobile banks (people know them as bank plecit, bank thithil, mbatak, or bank emok) are known by public as capital and or financing institutions with very high interest rates. The fact is so. It is no exaggeration if the rent seeking mobile banks are then perceived by the public as banks that do not help market merchants or debitors use their service, but instead undermine the business of merchants. Society in general refers to it as loan sharks.

Through qualitative approach, however, this study found that in the context of market merchants, in certain situations and conditions, choosing rent seeking mobile banks as an alternative of capital or financing is a rational economic action. There is no single reason for the market merchants to use rent seeking mobile banks' services. Cornered condition, as an example, is one of reasons but not the one reason.

The astounding other finding of this study is that there is no empirical and theoretical information and facts that the very high interest rate of rent seeking mobile bank results in involution or business degeneration.
\end{abstract}

Keywords: bank plecit, bank thithil, rent-seeking mobile bank, business involution, market merchants, capital and financing institutions, informal financial institutions, profit, economic action.

\begin{abstract}
Abstrak
Bank keliling pemburu rente (jamak dikenal sebagai bank plecit, bank thithil, mbatak, bank emok) dikenal masyarakat sebagai lembaga permodalan dan atau pembiayaan dengan mengenakan bunga amat tinggi. Faktanya memang demikian. Tak berlebihan bila bank ini kemudian dipersepsikan oleh masyarakat sebagai bank yang bukan membantu para pedagang pasar atau nasabah yang menggunakan jasa bank keliling pemburu rente, tetapi justru menggerogoti usaha para pedagang. Masyarakat pada umumnya menjulukinya dengan istilah rentenir.
\end{abstract}


Dengan pendekatan kualitatif, penelitian ini menemukan bahwa dalam konteks pedagang pasar, dalam situasi dan kondisi tertentu, pilihan alternatif permodalan atau pembiayaan bank keliling pemburu rente adalah pilihan yang rasional. Tidak ada alasan tunggal para pedagang pasar menggunakan jasa bank keliling pemburu rente. Terpepet, misalnya, adalah salah satu alasan; tetapi bukan satu-satunya alasan.

Hal menarik lain dari penelitian ini adalah tidak ditemukan informasi dan fakta empiris dan teoretis bahwa bunga bank keliling pemburu rente yang sangat tinggi tersebut mengakibatkan involusi atau pemerosotan usaha.

Kata kunci: bank plecit, bank keliling pemburu rente, involusi usaha, pedagang pasar, alternatif permodalan dan pembiayaan, lembaga keuangan informal, laba, tindakan ekonomis.

\section{PENDAHULUAN}

Badan Pusat Statistik (BPS) mengungkapkan bahwa angka kemiskinan di Indonesia pada Maret 2018 secara nasional berada pada tingkat 9,8\% (bps.go.id). Bila diangkakan, 9,8\% tersebut kira-kira sebanyak 25,9 juta jiwa. Jumlah ini kira-kira 16 kali penduduk Kota Semarang yang berjumlah sekitar 1,6 juta jiwa pada tahun yang sama (dispendukcapil.semarangkota.go.id). Di Kota Semarang, tercatat tingkat kemiskinan tersebut memang jauh lebih rendah dibandingkan dengan angka nasional. Tercatat, tingkat kemiskinan Kota Semarang pada periode yang sama sebesar 4,6\% (asatu.id). Namun, dengan jumlah penduduk Kota Semarang yang sekitar 1,6 juta jiwa di atas; jumlah orang miskin di Kota Semarang masih sekitar 70 - 80 ribu jiwa. Angka yang tidak kecil!

Di sisi lain, angka pengangguran terbuka per Agustus 2018 secara nasional berada pada angka 5,34\% atau kurang lebih sebanyak 7 juta orang (bps.go.id). Pada periode yang sama, angka pengangguran terbuka di Kota Semarang lebih tinggi daripada angka nasional, yaitu sebesar 6,61\% atau sekitar 67.000 orang (jatengtoday.com). Di sisi lain lagi, Indef mencatat, daya serap pertumbuhan ekonomi terhadap tenaga kerja juga sangat rendah, yakni 120.000 orang per 1\% pertumbuhan ekonomi (menara62.com). Dengan pertumbuhan ekonomi nasional berkisar 5\% per tahun, itu berarti bahwa pemerintah hanya mampu menyerap kurang lebih 600.000 orang angkatan kerja per tahun. Apabila pertumbuhan angkatan kerja nol saja, pemerintah butuh waktu hampir 12 tahun untuk menyerap pengangguran terbuka sejumlah 7 juta orang di atas. Padahal, kenyataannya, angkatan kerja terus bertumbuh setiap tahunnya. 
Pada titik itulah sektor informal menjadi demikian penting. Sektor informal menjadi alternatif pemecahan masalah, baik masalah pengangguran maupun masalah kemiskinan (baca: Pitoyo, 2007; hlm. 131, 136; Bappenas, 2009, hlm. 2). Mereka yang tidak terserap oleh sektor formal akan terjun ke dalam sektor informal dengan usaha kecil-kecilan. Usaha kecil-kecilan ini bisa berupa pedagang kaki lima, penjual bakso, asongan, dll. selain juga jasa angkutan, misalnya tukang ojek, tukang becak, dan industri rumahan, termasuk pedagang kecil di pasar. Dan, sejarah membuktikan bahwa sektor informal justru merupakan sektor yang sama sekali tidak terpengaruh krisis. Bahkan, 30-70\% tenaga kerja di negara berkembang seperti Indonesia bekerja di sektor informal (Bappenas, 2009). Itu berarti bahwa sektor informal memiliki peran signifikan bagi perekonomian nasional maupun regional.

Selain biasanya tidak terorganisasi, tidak teratur, legal tetapi tidak terdaftar (Bappenas, 2009); sektor informal biasanya menghadapi kendala dalam hal akses permodalan. Karena berbagai sebab, kesulitan permodalan tersebut mereka tutupi dengan meminjam uang ke lembaga permodalan atau pembiayaan bank keliling pemburu rente (rent-seeking mobile bank), yang jamak dikenal dengan sebutan bank plecit $^{1}$.

Problemnya, bank keliling pemburu rente menetapkan bunga sangat tinggi, yakni $20 \%$ bahkan lebih dari $30 \%$ per periode. Satu periode pinjaman bervariasi, dari 10 hari hingga 16 minggu. Tingkat bunga ini amat mencekik dibandingkan dengan, misalnya, bunga Kredit Usaha Rakyat Bank BRI yang hanya 7\% per tahun atau setara $0,41 \%$ per bulan flat atau kurang lebih 0,02\% per hari (bri.co.id; diakses 8 Maret 2019). Saking tingginya tingkat bunga yang diterapkan bank keliling pemburu rente, tak jarang nasabah bukannya tertolong, melainkan justru terlilit persoalan bunga berbunga. PD (64 tahun), misalnya, bahkan pernah sampai mau bunuh diri dengan meminum pestisida lantaran tak kuat dengan masalah utang-piutang dengan bank plecit tersebut

\footnotetext{
${ }^{1}$ Bank plecit adalah istilah yang dipakai untuk menunjuk sebuah lembaga alternatif permodalan dan atau pembiayaan dengan tingkat bunga sangat tinggi dibandingkan dengan lembaga-lembaga permodalan atau pembiayaan formal, misalnya bank atau pegadaian. Bank ini biasanya menarik nasabah di pasar-pasar tradisional atau perkampungan. Istilah lain untuk bank plecit adalah bank thithil, bank emok, mbatak. Sebagian orang mengenalnya sebagai 'bank keliling' mengacu pada cara kerja lembaga permodalan tersebut yang menarik nasabah dan menagih cicilan dengan cara berkeliling. Akan tetapi, beberapa bank konvensional pun memiliki program dengan cara kerja yang sama: menarik tabungan atau mencari nasabah dengan jemput bola (berkeliling). Oleh karena itu, istilah 'bank keliling' untuk menunjuk secara spesifik lembaga permodalan bank plecit tidak begitu tepat. Sebagian lagi ada yang menyebutnya sebagai lembaga keuangan illegal. Istilah ini juga tidak begitu tepat sebab faktanya bank-bank tersebut adalah lembaga yang memiliki izin sah secara hukum. Oleh karena itu, istilah yang paling tepat untuk menunjuk lembaga permodalan atau pembiayaan semacam bank plecit adalah bank keliling pemburu rente (rent-seeking mobile bank). Untuk selanjutnya, tulisan ini akan menggunakan istilah bank keliling pemburu rente atau bank plecit.
} 
(Koranmemo.com). Seorang ibu di Jogja harus kucing-kucingan dengan debt collector bank plecit lantaran tidak kuat dengan perlakuan kasar ketika penagihan. Ia harus membayar bunga 25 ribu per hari untuk hutang yang ia ambil dari sebuah bank plecit senilai Rp5 juta. Ia sudah membayar bunga tersebut selama 8 tahun.

Sekalipun terbukti bahwa bank keliling pemburu rente tidak membantu menyelesaikan masalah permodalan bahkan sering kali justru menimbulkan masalah, faktanya para debitur yang notabene adalah para pelaku usaha sektor informal tetap menggunakan jasa mereka. Seorang pedagang sebut saja Sis (55) di Semarang Selatan mengaku dirinya sering meminjam uang pada bank keliling pemburu rente sekalipun dia tahu bunga bank ini sangat tinggi (radarsemarang.com). Radar Semarang menelusuri bahwa di Pasar Mangkang saja, jumlah bank plecit ada 10 buah; sedangkan di Pasar Karangayu ada sekitar 20 pelaku. Bank plecit tidak mungkin eksis bila tidak ada permintaan!

Dalam konteks pengembangan usaha, karena bunga bank keliling pemburu rente terlampau tinggi, apabila margin keuntungan nasabah tidak bisa menutupi tingkat bunga bank tersebut, sangat logis bila ditengarai penggunaan modal dari bank keliling pemburu rente justru akan menggerogoti modal awal. Dengan demikian, penambahan modal yang seharusnya berdampak pada pengembangan usaha, dengan kasus seperti di atas, bukan tidak mungkin nasabah justru mengalami pemerosotan usaha (involusi).

Muncullah pertanyaan, mengapa para pedagang pasar masih tetap menggunakan jasa bank keliling pemburu rente sebagai alternatif permodalan mereka sekalipun terbukti bunga bank keliling pemburu rente sangat mencekik. Apakah ada fakta empiris bahwa pedagang pasar mengalami involusi dikarenakan oleh penggunaan jasa bank keliling pemburu rente.

Sejauh peneliti telusuri, belum ada studi yang mengaitkan antara bank keliling pemburu rente dengan involusi usaha pedagang pasar. Penelitian Adrin Ali Hamka (2010) yang dimuat dalam Journal of Indonesia Applied Economics menelaah bank plecit, tetapi fokus penelitiannya pada bagaimana eksistensi bank plecit. Penelitian ini dilakukan dengan metode fenomenologi dengan locus penelitian Pasar Kota Batu, Malang. Demikian juga penelitian Ahmad Yunadi (2011) yang dimuat Jurnal Ekonomi Syariah Indonesia, Ratna Setyo Utami (Fakultas Keguruan dan Ilmu Pendidikan Program Studi Pendidikan Ekonomi Universitas Sanata Dharma, Yogyakarta, 2007), 
Dian Pertiwi (Fakultas Ilmu Sosial dan Humaniora Program Studi Sosiologi Universitas Universitas Islam Negeri Sunan Kalijaga, Yogyakarta, 2017), Diana Paramitasari (Pendidikan Sosiologi dan Antropologi Fakultas Ilmu Sosial Universitas Negeri Semarang, 2016), Tini Hayatur Rohmah (Program Studi Hukum Ekonomi Syariah IAIN Purwokerto, 2017); belum satu pun yang mengaitkan antara bank keliling pemburu rente dengan involusi usaha pedagang pasar.

Tulisan ini hendak menguraikan alasan para pedagang pasar tetap menggunakan jasa bank keliling pemburu rente sebagai alternatif permodalan dan atau pembiayaan. Selain itu, tulisan ini juga berupaya mengungkap apakah ada bukti empiris dan teoretis pedagang pasar mengalami involusi karena menggunakan jasa bank keliling pemburu rente.

\section{TINJAUAN PUSTAKA}

\section{Involusi}

Awal mula bencana pertanian itu terjadi ketika Gubernur Jenderal Hindia Belanda van Den Bosch ketika itu membebaskan petani dari pajak tanah dan sebagai gantinya petani harus menanam tebu, kopi, nila dll sebagai tanaman ekspor milik pemerintah di atas seperlima sawah petani. Kebijakan fiskal tersebut kemudian dikenal sebagai Sistem Tanam Paksa (Cultuurstelsel). Tanah Jawa yang luasnya hanya 19\% dari seluruh luas wilayah Indonesia tetapi dihuni $70 \%$ dari total penduduk, tanah yang sama kini harus menanggung beban tambahan berupa pajak sebesar 20\% (Geertz, 1983; 12-55). Terjadilah apa yang disebut sebagai dualisme ekonomi Hindia Belanda. Di satu sisi terdapat ekonomi ekspor dengan dukungan kapitalisme dan bersandar pada produk gula, kopi, tembakau, nila dsb; di sisi lain terdapat ekonomi pedesaan yang menghasilkan pangan sambil dipaksa memberikan subsidi terhadap sektor pertama (Sajogjo dalam Geertz, 1983; xxi).

Karena tanaman ekspor (khususnya gula, dalam konteks ini) mengambil seperlima luas sawah yang tadinya ditanami padi, dengan sendirinya luas persawahan padi menjadi berkurang 20\%. Padahal, di sisi lain, jumlah penduduk terus bertambah. Dengan demikian tampaklah bahwa persawahan kini menghadapi dua tekanan sekaligus: tekanan eksternal berasal dari keharusan menanam tebu dari pemerintah Hindia Belanda, tekanan internal berasal dari jumlah penduduk yang terus bertambah. 
Sawah harus tetap menampung tenaga kerja yang terus-menerus lahir akibat pertumbuhan penduduk. Berbeda dengan kondisi Indonesia luar-istilah Geertz untuk menunjuk luar Jawa_pada persawahan Jawa tidak mungkin dilakukan ekstensifikasi. Mengapa? Petani tidak memiliki cukup modal untuk membuka sawah baru. Oleh karena itu, karena tidak ada cara lain untuk mengalihkan kelebihan tenaga kerja di sawah, satusatunya upaya untuk menampung tenaga kerja tersebut adalah dengan intensifikasi. Kondisi semacam ini tidak terjadi pada pertanian ladang di luar Jawa. Di luar Jawa, ketika penduduk bertambah, petani bisa dengan mudah membuka ladang baru, misalnya dengan pertanian tebang-bakar.

Dengan sistem intensifikasi, benar bahwa sawah mampu meningkatkan produksinya. Sekalipun, Geertz memberi catatan bahwa tanah sawah pada hakikatnya tidak akan kehilangan daya hasilnya walaupun lama tidak dipupuk. Ini terjadi karena adanya faktor air dalam sistem irigasi yang melekat pada tanah sawah (Geertz, 1983; 29). Produksi padi secara total memang meningkat, tetapi ketika dicermati lebih dalam, produksi padi per kapita ternyata menurun. Dengan kata lain, daya hasil dari sawah itu sendiri memang tidak berkurang; tetapi daya topangnya terhadap pekerja merosot. Sawah selalu menampung setiap kelebihan tenaga kerja, tetapi bagaimanapun akan timbul kemerosotan. Proses inilah yang dinamakan involusi pertanian (Geertz, 1983; 75).

Clifford Geertz adalah ilmuwan yang menggunakan istilah involusi ketika menjelaskan proses "kemunduran" pertanian di Jawa (Agricultural Involution). Istilah ini kemudian menjadi istilah yang elastis (baca Kitley, 1992; Freedman, Hammar, 1988). Terlepas dari berbagai debat dan perbedaan tafsir atas kata 'involusi', para peneliti sepakat bahwa dalam konteks pertanian di Jawa, involusi memiliki ciri-ciri kompleksitas (complexity), elaborasi (elaboration), dan pengulangan (repetitiousness). Bagi Geertz, intensifikasi pertanian yang berlangsung amat lama di Indonesia telah menimbulkan kompleksitas sosial yang lebih besar tanpa perubahan yang signifikan dalam bidang teknologi dan politik. Dalam hal ini, involusi dimaksudkan sebagai suatu proses pertanian di Jawa di mana permintaan dari para penguasa Belanda (faktor eksternal) dan tekanan pertumbuhan penduduk (faktor internal) mendorong intensifikasi dan bukan perubahan. 
Involusi usaha secara ringkas bisa diartikan sebagai kemerosotan usaha (Pormes, 2015). Dalam konteks pedagang pasar, terjadi atau tidaknya involusi usaha bisa dilihat dari bertambah atau berkurangnya modal yang dimiliki. Semakin modal awal yang dimiliki termakan untuk mempertahankan usaha; berarti usaha tersebut semakin mengalami involusi. Sebagaimana yang terjadi dalam involusi pertanian menurut kajian Geertz, sepintas lalu para pedagang pasar yang menggunakan jasa bank keliling pemburu rente ini juga menghadapi baik tekanan eksternal maupun internal. Tekanan eksternal berasal dari 'kewajiban' membayar bunga sangat tinggi dari bank plecit sedangkan tekanan internal berasal dari 'beban biaya hidup' untuk keluarga.

Simulasi hipotetis pada tabel 1 memperjelas maksud ini. Secara matematis, sekalipun bank plecit menetapkan bunga amat tinggi (20-31\%), dengan asumsi pedagang setiap hari memutar modal yang diperolehnya dari bank plecit dengan margin keuntungan 10\% saja; hal itu tetap menguntungkan pedagang. (lihat tabel 1)

\section{Profit}

Ilmu ekonomi mengajarkan bahwa Profit $=$ Total Revenue $(\mathrm{TR})-$ Total Cost $(\mathrm{TC})$ (Boediono, 2008; Salvatore, 2016; Gilarso, 2014; Mankiw, 2012). Ini berarti bahwa bila TR lebih besar daripada TC, profit positif (untung). Sebaliknya, bila TR lebih kecil daripada TC, profit negatif (rugi).

Bagi pedagang pasar, secara sederhana profit merupakan selisih dari harga jual dan harga beli. Apabila seorang pedagang wortel membeli wortel Rp5.000/kilogram (harga beli wortel Rp4.900/kg+ongkos angkut Rp100/kg) dan dijual Rp5.500/kg; si pedagang mendapatkan untung Rp500/kg atau 10\%. Tetapi, dalam praktiknya, tidak jarang pedagang pasar menggunakan kredit untuk modal usahanya. Dalam kredit, ada variabel bunga yang secara teoretis juga perlu dimasukkan sebagai biaya.

Sehingga, misalnya pedagang wortel di atas membeli barang dagangannya dengan memakai kredit dengan bunga 2\%; keuntungan pedagang wortel tersebut bukan lagi Rp500/kg atau 10\%; melainkan Rp500-(2\% x Rp500) = Rp490 (9,8\%).

\section{Bank Keliling Pemburu Rente}

Bank keliling pemburu rente atau umumnya dikenal sebagai bank plecit adalah istilah untuk alternatif pembiayaan yang biasanya beroperasi di pasar-pasar atau kampung-kampung. Istilah lain untuk bank plecit adalah bank titil atau Mbatak atau 
rentenir (Yunadi, 2011; Utami, 2007; Pertiwi, 2017; Paramitasari, 2016). Kata plecit dalam bahasa Jawa berarti dikejar-kejar atau ditekan (Pertiwi, 2017). Pertiwi tidak menjelaskan lebih jauh, mengapa kata plecit tersebut dilekatkan pada bank keliling pemburu rente. Mengapa disebut rentenir? Karena alternatif pembiayaan ini memberikan kredit dengan bunga yang jauh lebih tingga daripada bunga yang diterapkan oleh lembaga pembiayaan resmi (Bank). Bank plecit menetapkan bunga antara $20-31 \%$.

\section{Telaah Penelitian Sebelumnya}

Sejauh peneliti telusuri, belum ada penelitian yang mengaitkan antara penggunaan modal yang berasal dari bank plecit dengan involusi usaha. Beberapa penelitian yang langsung atau tidak langsung terkait bank plecit memang telah dilakukan, antara lain sebagai berikut.

a. Penelitian yang dilakukan oleh Ahmad Yunadi (dalam Jurnal Ekonomi Syariah Indonesia), 2011. Yunadi meneliti adakah hubungan antara tingkat religiusitas pedagang sayur di Pasar Giwangan, Yogyakarta dengan pembiayaan mudharabah. Hasil penelitian Yunadi menyimpulkan bahwa faktor religiusitas bukanlah faktor utama pemilihan pembiayaan mudharabah oleh pedagang sayur di Pasar Giwangan.

b. Penelitian yang dilakukan Ratna Setyo Utami (Fakultas Keguruan dan Ilmu Pendidikan Program Studi Pendidikan Ekonomi Universitas Sanata Dharma, Yogyakarta), 2007. Dalam penelitian ini, Utami berfokus pada bagaimana bank plecit beroperasi: bagaimana memperoleh nasabah, bagaimana menetapkan tingkat bunga, pertimbangan-pertimbangan dalam memberikan kredit, dan penanganan kredit macet. Penelitian dilakukan pada pedagang Pasar Desa Ngrambe, Ngawi, Jawa Timur.

c. Penelitian yang dilakukan Dian Pertiwi (Fakultas Ilmu Sosial dan Humaniora Program Studi Sosiologi Universitas Islam Negeri Sunan Kalijaga, Yogyakarta), 2017. Penelitian dilakukan Dian Pertiwi di Kampung Gendingan, Yogyakarta. Penelitian ini menjawab pertanyaan mengapa penduduk Kampung Gendingan, Yogyakarta tergantung pada bank plecit. Dian Pertiwi menemukan bahwa hal tersebut terjadi karena faktor habitus. 
d. Penelitian Diana Paramitasari (Pendidikan Sosiologi dan Antropologi Fakultas Ilmu Sosial Universitas Semarang), 2016. Penelitian dilakukan di Pasar Jatisrono, Wonogiri. Paramitasari meneliti topik hubungan sosial-ekonomi antara pedagang pasar di Pasar Jatisrono dengan Mbatak (istilah lain bank plecit). Paramitasari menyimpulkan bahwa Mbatak tetap eksis di pasar lantaran adanya hubungan simbiosis-mutualisme antara para pedagang dengan Mbatak itu sendiri. Dari sisi pedagang pasar, mereka membutuhkan Mbatak karena faktor banyaknya kebutuhan. Apakah penggunaan dana dari Mbatak tersebut justru memperkecil usaha (involusi) para pedagang pasar, oleh penelitian ini belum diungkap.

e. Tini Hayatur Rohmah (Program Studi Hukum Ekonomi Syariah IAIN Purwokerto), 2017. Penelitian dilakukan di Kecamatan Patikraja, Banyumas. Tabel 1 SIMULASI PERPUTARAN MODAL

\begin{tabular}{|c|c|c|c|c|c|c|c|c|}
\hline HARI & $\begin{array}{c}\text { MODAL KERJA } \\
\text { AWAL }\end{array}$ & KREDIT & $\begin{array}{l}\text { TOTAL MODAL } \\
\text { KERJA }\end{array}$ & $\begin{array}{l}\text { KEUNTUNGAN } \\
\text { DAGANG (10\%) }\end{array}$ & $\begin{array}{c}\text { BUNGA KREDIT } \\
(25 \%)\end{array}$ & $\begin{array}{l}\text { CICILAN } \\
\text { KREDIT }\end{array}$ & $\begin{array}{c}\text { TOTAL MODAL } \\
\text { AKHIR }\end{array}$ & $\begin{array}{l}\text { MODAL AKHIR } \\
\text { SENDIRI }\end{array}$ \\
\hline 0 & - & 500.000 & 400.000 & 40.000 & & & 440.000 & 90.000 \\
\hline 1 & & & 440.000 & 44.000 & 5.208 & 20.833 & 457.958 & 67.958 \\
\hline 2 & & & 457.958 & 45.796 & 5.208 & 20.833 & 477.713 & 69.755 \\
\hline 3 & & & 477.713 & 47.771 & 5.208 & 20.833 & 499.443 & 71.730 \\
\hline 4 & & & 499.443 & 49.944 & 5.208 & 20.833 & 523.346 & 73.903 \\
\hline 5 & & & 523.346 & 52.335 & 5.208 & 20.833 & 549.639 & 76.293 \\
\hline 6 & & & 549.639 & 54.964 & 5.208 & 20.833 & 578.562 & 78.923 \\
\hline 7 & & & 578.562 & 57.856 & 5.208 & 20.833 & 610.376 & 81.815 \\
\hline 8 & & & 610.376 & 61.038 & 5.208 & 20.833 & 645.373 & 84.996 \\
\hline 9 & & & 645.373 & 64.537 & 5.208 & 20.833 & 683.869 & 88.496 \\
\hline 10 & & & 683.869 & 68.387 & 5.208 & 20.833 & 726.214 & 92.346 \\
\hline 11 & & & 726.214 & 72.621 & 5.208 & 20.833 & 772.794 & 96.580 \\
\hline 12 & & & 772.794 & 77.279 & 5.208 & 20.833 & 824.032 & 101.238 \\
\hline 13 & & & 824.032 & 82.403 & 5.208 & 20.833 & 880.394 & 106.362 \\
\hline 14 & & & 880.394 & 88.039 & 5.208 & 20.833 & 942.392 & 111.998 \\
\hline 15 & & & 942.392 & 94.239 & 5.208 & 20.833 & 1.010 .590 & 118.198 \\
\hline 16 & & & 1.010 .590 & 101.059 & 5.208 & 20.833 & 1.085 .608 & 125.018 \\
\hline 17 & & & 1.085 .608 & 108.561 & 5.208 & 20.833 & 1.168 .127 & 132.519 \\
\hline 18 & & & 1.168.127 & 116.813 & 5.208 & 20.833 & 1.258 .899 & 140.771 \\
\hline 19 & & & 1.258 .899 & 125.890 & 5.208 & 20.833 & 1.358 .747 & 149.849 \\
\hline 20 & & & 1.358 .747 & 135.875 & 5.208 & 20.833 & 1.468 .581 & 159.833 \\
\hline 21 & & & 1.468 .581 & 146.858 & 5.208 & 20.833 & 1.589 .397 & 170.817 \\
\hline 22 & & & 1.589 .397 & 158.940 & 5.208 & 20.833 & 1.722 .296 & 182.898 \\
\hline 23 & & & 1.722 .296 & 172.230 & 5.208 & 20.833 & 1.868 .484 & 196.188 \\
\hline 24 & & & 1.868 .484 & 186.848 & 5.208 & 20.833 & 2.029 .291 & 210.807 \\
\hline & & & & 2.254 .283 & 125.000 & 499.992 & & \\
\hline & Kredit 500.000 & & & & & & & \\
\hline & Biaya Adm. 10\% & & & & & & & \\
\hline & \multicolumn{2}{|c|}{ Ditahan sebagai tabungan $10 \%$} & & & & & & \\
\hline & \multicolumn{2}{|c|}{ Cicilan selama 24 hari } & & & & & & \\
\hline & \multicolumn{2}{|c|}{ Bunga kredit $25 \%$ flat } & & & & & & \\
\hline
\end{tabular}


Dalam penelitian ini, Rohmah berfokus menyoroti bank plecit dari sudut pandang hukum Islam.

\section{METODOLOGI}

Penelitian ini dilakukan dengan pendekatan kualitatif. Pendekatan kualitatif dipilih karena peneliti bermaksud menggambarkan (deskriptif) dan menjelaskan (eksplanatoris) mengapa para pedagang pasar tetap menggunakan bank keliling pemburu rente sebagai alternatif permodalan. Dengan demikian, penelitian ini sekaligus bercorak deskriptifeksplanatoris. Penelitian desriptif berarti penelitian untuk menggambarkan fenomnea sosial yang ada di dalam masyarakat sedangkan penelitian eksplanatoris adalah penelitian yang menjelaskan atau menunjukkan dan menspesifikasi sebab-sebab yang memungkinkan munculnya gejala sosial tersebut (Suwondo, 2005).

Pemilihan pendekatan ini didukung oleh pendapat Sutton (2015) yang menyatakan, "What qualitative study seeks to convey is why people have thoughts and feelings that might affect the way they behave." Selain itu, penelitian ini juga bertujuan menjelaskan apakah tingkat bunga yang terlalu tinggi tersebut menyebabkan involusi terhadap usaha para pedagang pasar. Dengan demikian, data deskriptif yang diperoleh adalah kata-kata tertulis atau lisan dan perilaku yang bisa diamati (Moleong, 2005). Sekalipun demikian, penelitian ini tidak dimaksudkan untuk menggeneralisasi temuan (Sutton, 2015).

Data primer diambil dengan teknik purposive-snowball random sampling. Dalam hal ini, peneliti menggunakan metode indepth interview dan pengamatan. Metode ganda (multi-methods) atau yang sering dikenal dengan istilah triangulasi diterapkan untuk menjamin konsistensi dan validitas informasi (Quick, 2015).

Informan kunci dalam penelitian ini adalah pedagang pasar di Semarang, pengguna jasa bank keliling pemburu rente. Mereka adalah pedagang pasar di Pasar Karangayu, Pasar Gayamsari, Pasar Johar Baru (relokasi Pasar Johar lama), dan Pasar Peterongan. Pada awalnya agak sulit menemukan nasabah bank keliling pemburu rente. Beberapa kali peneliti langsung mewawancarai pedagang pasar, tetapi mereka menolak dengan alasan tidak tahu. Oleh karena itu, peneliti selanjutnya menggunakan teknik lain. Peneliti mengamati penagih bank keliling pemburu rente. Penampilan mereka rata-rata mudah ditebak. Membawa tas, notes dan yang paling valid: mereka menarik tagihan, mencatat di notes dan memberikan sobekan kertas setoran. Kepada nasabah yang baru saja didatangi penagih hutang, peneliti langsung mendatangi nasabah tersebut. Dengan 
demikian, nasabah tidak punya alasan untuk menolak wawancara dengan dalih tidak mengenal atau tidak mengetahui bank keliling pemburu rente.

\section{Pengolahan Data dan Analisis}

Semua wawancara terhadap informan kunci direkam. Wawancara berlangsung sekitar 30 hingga 60 menit. Hasil wawancara tersebut ditranskrip. Dalam proses ini peneliti akan menambahkan catatan-catatan lapangan (field notes) untuk lebih memahami konteks. Misalnya, mimik wajah informan ketika menjawab pertanyaan tertentu, nada suara, tempo bicara, dsb.

Setelah semua rekaman hasil wawancara ditranskrip dan diedit; peneliti selanjutnya mengelompokkan semua jawaban informan sesuai dengan pertanyaan. Misalnya, terhadap pertanyaan "Tolong ceritakan bagaimana pada awalnya Anda meminjam bank plecit"; semua jawaban informan atas pertanyaan tersebut dijadikan satu. Proses ini oleh Suton (2015) disebut sebagai manajemen data.

\section{Tabel 2}

Contoh Pengelompokan Jawaban Informan

\begin{tabular}{|c|c|c|c|c|}
\hline Informan 1 & Informan 2 & Informan 3 & Informan 4 & Informan 5 \\
\hline \multicolumn{5}{|c|}{$\begin{array}{l}\text { Pertanyaan 1: Tolong ceritakan bagaimana awalnya Anda berhutang di bank } \\
\text { plecit. }\end{array}$} \\
\hline $\begin{array}{l}\text { Dia kan dating } \\
\text { sendiri. Saya } \\
\text { tidak tahu } \\
\text { nama banknya, } \\
\text { alamat } \\
\text { kantornya. "Bu } \\
\text { kalau butuh } \\
\text { dana?" lalu } \\
\text { saya ambil. }\end{array}$ & $\begin{array}{l}\text { Ada orang yang } \\
\text { dating } \\
\text { menawari jadi } \\
\text { ya saya ambil. } \\
\text { Ini bukan bank } \\
\text { tapi koperasi. } \\
\text { Bedanya apa? } \\
\text { (agak lama } \\
\text { menjawab). } \\
\text { Kalau koperasi } \\
\text { itu kan itu } \\
\text { lho... carane } \\
\text { wonten } \\
\text { nasabah... eh, } \\
\text { nopo... ada } \\
\text { karyawannya } \\
\text { yang ke sini. }\end{array}$ & $\begin{array}{l}\text { Koperasi yang } \\
\text { datang nawari. }\end{array}$ & $\begin{array}{l}\text { Dulu } \\
\text { ditawari... } \\
\text { banknya } \\
\text { datang, } \\
\text { ditawari. Tapi, } \\
\text { pinjamnya ya } \\
\text { kalau pas } \\
\text { pinjam kalau } \\
\text { pas sepi ya } \\
\text { tidak (suara } \\
\text { agak meninggi) }\end{array}$ & $\begin{array}{lr}\text { Saya } & \text { tidak } \\
\text { berani } & \text { pinjam. } \\
\text { Saya } & \text { tidak } \\
\text { pernah } & \text { pakai } \\
\text { rentenir } & \text { itu. } \\
\text { Maaf. } & \text { Saya } \\
\text { takut. } & \\
\end{array}$ \\
\hline
\end{tabular}

Dengan cara ini peneliti dengan mudah membandingkan jawaban-jawaban informan terhadap pertanyaan yang sama. 
Langkah selanjutnya peneliti menentukan kata-kata kunci berdasarkan jawaban para informan di atas. Misalnya: terpepet, tanpa jaminan, prosesnya mudah, dst. Kemudian peneliti sekali lagi membuat tabel berisi kata-kata kunci yang telah ditentukan berdasarkan jawaban para informan pada tabel sebelumnya. Tabel ini dibuat untuk melihat pola yang terjadi. Karena hanya untuk melihat pola, peneliti cukup mengisi kotak dengan tanda ' $x$ ' untuk informan yang menginformasikan kata kunci tersebut dan mengosongkan kotak untuk informan yang tidak memberikan informasi atas kata kunci tersebut. Tabel 3 menggambarkan contoh langkah ini.

Tabel 3

Contoh Pola Jawaban Informan

\begin{tabular}{|l|l|l|l|l|l|l|l|}
\hline NO & THEME & INF 1 & INF 2 & INF 3 & INF 4 & INF 5 & KET. \\
\hline 1 & $\begin{array}{l}\text { Terpepet } \\
\text { Kebutuhan }\end{array}$ & $\mathrm{x}$ & $\mathrm{x}$ & $\mathrm{x}$ & & & Membayar SPP anak. \\
\hline 2 & $\begin{array}{l}\text { Pengetahuan } \\
\text { mengenai bunga }\end{array}$ & $\mathrm{x}$ & $\mathrm{x}$ & $\mathrm{x}$ & $\mathrm{x}$ & $\mathrm{x}$ & \\
\hline 3 & Tanpa jaminan & $\mathrm{x}$ & $\mathrm{x}$ & $\mathrm{x}$ & $\mathrm{x}$ & & \\
\hline 4 & Dst. & & & & & & \\
\hline
\end{tabular}

Setelah pola diketahui, peneliti menentukan tema-tema untuk dilaporkan. Misalnya: Motif, Penggunaan dana, involusi, dsb. Langkah terakhir adalah menyusun laporan penelitian.

\section{HASIL DAN PEMBAHASAN}

\section{A. Bank Keliling Pemburu Rente}

Bank keliling pemburu rente (rent-seeking mobile banks) merupakan salah satu alternatif permodalan yang akrab dikenal masyarakat, termasuk dan terutama di kalangan pedagang pasar. Lembaga permodalan ini jamak dikenal sebagai bank thithil (Semarang, Jawa Tengah; Malang dan Blitar, Jawa Timur), bank plecit (Yogyakarta), bank emok (Karawang, Jawa Barat), atau mbatak (Wonogiri, Jawa Tengah) (baca Elisa dan Zuhroh, 2017; Hamka dan Danarti, 2010; Pertiwi, 2017; Paramitasari, 2016; Utami, 2007). Beberapa di antaranya bukan lembaga keuangan resmi (misalnya perorangan), beberapa yang lain berkedok koperasi. 


\section{Rentenir}

Apa pun namanya, masyarakat awam bahkan sebagian pedagang pasar menyebut bank keliling pemburu rente sebagai rentenir. "Saya tidak berani pinjam. Saya tidak pernah pakai rentenir itu. Maaf, saya takut,"2 kata seorang informan di Pasar Gayamsari ketika ditanya mengenai bank plecit. Sebutan rentenir tersebut disematkan pada bank plecit bukan tanpa sebab. Bank ini mengenakan tarif bunga pinjaman yang kelewat tinggi, antara 20-30\% (lihat tabel 4).

Eko, seorang salesman merangkap debt collector sebuah Koperasi Simpan Pinjam $(\mathrm{KSP})^{3}$ berpusat di Jepara, Jawa Tengah yang berkantor di seputar Lapangan Banteng, Semarang bercerita.

Pinjaman Rp1.000.000 menjadi Rp1.200.000. Rpl,2 juta tersebut

dicicil selama 12 kali. Satu kali cicilan Rp100.000. ${ }^{4}$

Berdasarkan cerita Eko, sepintas bunga yang dikenakan bank plecit adalah $20 \%$ per periode (12 kali cicilan atau 12 hari). Akan tetapi, apabila ditelusuri lebih dalam, bunga yang dibebankan bank plecit sebenarnya jauh lebih besar daripada 20\%. Sri Sulastri sebagai nasabah Eko memberikan data di bawah ini. ${ }^{5}$

Sri Sulastri mengambil pinjaman sebesar Rp1.000.000. Uang tunai yang diterima Sulastri ternyata hanya Rp900.000 karena ketika pinjaman tersebut cair pihak bank secara otomatis memotong Rp50.000 sebagai biaya administrasi dan Rp50.000 selebihnya sebagai tabungan. Tabungan ini hanya bisa diambil Sulastri apabila dia sudah mencicil selama 10 kali. Itupun, tabungan tersebut tidak bisa diambil dalam bentuk uang tunai melainkan hanya bisa dipakai untuk mengangsur cicilan.

Dengan demikian, beban bunga yang ditanggung oleh Sri Sulastri adalah sebesar (total angsuran - total pinjaman yang diterima): total pinjaman yang diterima.

$=(1.200 .000-950.0000: 950.000$

$=26,3 \%$.

Semua informan menceritakan pola yang sama mengenai sistem tersebut, yaitu bahwa $10 \%$ dari nilai pinjaman akan dipotong (5\% untuk biaya administrasi dan 5\% sebagai tabungan) oleh pihak bank.

\footnotetext{
${ }^{2}$ Wawancara 18 Juli 2019

${ }^{3}$ Pada umumnya lembaga pembiayaan bank keliling pemburu rente menggunakan kedok lembaga Koperasi. Seorang informan di

Pasar Karangayu bahkan menyebut bank keliling pemburu rente ini bukan bank thithil melainkan koperasi (wawancara 16 Juli 2019 ).

${ }^{4}$ Wawancara 15 Juli 2019

${ }^{5}$ Wawancara 15 Juli 2019
} 
Tabel 4.

Besaran Bunga Pinjaman Bank Keliling Pemburu Rente

\begin{tabular}{|c|c|c|c|}
\hline NO & INFORMAN & $\begin{array}{l}\text { BESAR } \\
\text { PINJAMAN }\end{array}$ & BESAR BUNGA PINJAMAN \\
\hline \multirow[t]{2}{*}{1} & \multirow[t]{2}{*}{ Informan 1} & 1.000 .000 & $\begin{array}{l}\text { Terima tunai: } 900.000 \\
\text { Cicilan: } 120.000 \times 10 \mathrm{kali} \\
\text { Bunga }= \\
950.000 \\
=\mathbf{2 6 , 3 \%}\end{array}$ \\
\hline & & 500.000 & $\begin{array}{l}\text { Terima tunai: } 450.000 \\
\text { Cicilan: } 60.000 \times 10 \mathrm{kali} \\
\text { Bunga }=(600.000-475.000): 475.000 \\
=\mathbf{2 6 , 3 \%}\end{array}$ \\
\hline 2 & Informan 2 & 5.000 .000 & $\begin{array}{l}\text { Terima tunai: } 4.500 .000 \\
\text { Cicilan: } 65.000 \times 100 \mathrm{kali} \\
\text { Bunga = } \quad(6.500 .000-4.750 .000): \\
4.750 .000 \\
=\mathbf{3 1 , 5 \%}\end{array}$ \\
\hline \multirow[t]{2}{*}{3} & \multirow[t]{2}{*}{ Informan 3} & 1.000 .000 & $\begin{array}{l}\text { Terima tunai: } 900.000 \\
\text { Cicilan : } 100.000 \times 12 \mathrm{kali} \\
\text { Bunga: } \\
950.000): 950.000 \\
=\mathbf{2 6 , 3 \%}\end{array}$ \\
\hline & & 200.000 & $\begin{array}{l}\text { Terima tunai: } 180.000 \\
\text { Cicilan: } 10.000 \times 24 \text { kali } \\
\text { Bunga: }(240.000- \\
190.000 \\
=\mathbf{2 1 \%}\end{array}$ \\
\hline 4 & Informan 4 & 2.000 .000 & $\begin{array}{l}\text { Terima tunai: } 1.800 .000 \\
\text { Cicilan: } 300.000 \times 8 \\
\text { Bunga: } \quad(2.400 .000-1.900 .000) \text { : } \\
1.900 .000 \\
=\mathbf{2 6 \%}\end{array}$ \\
\hline
\end{tabular}

Tabel 5.

Tingkat Bunga Harian

\begin{tabular}{|l|l|l|l|l|}
\hline NO & INFORMAN & $\begin{array}{l}\text { Tingkat Bunga/ } \\
\text { Periode }\end{array}$ & $\begin{array}{l}\text { Periode } \\
\text { Pinjaman }\end{array}$ & $\begin{array}{l}\text { Tingkat Bunga } \\
\text { per Hari }\end{array}$ \\
\hline 1 & \multirow{2}{*}{ Informan 1 } & $26,3 \%$ & 10 minggu & $0,43 \%$ \\
\cline { 3 - 5 } & & $26,3 \%$ & 10 hari & $2,63 \%$ \\
\hline 2 & Informan 2 & $31,5 \%$ & 100 hari & $0,31 \%$ \\
\hline 3 & \multirow{2}{*}{ Informan 3 } & $26,3 \%$ & 12 minggu & $0,36 \%$ \\
\cline { 3 - 5 } & & $21 \%$ & 24 hari & $0,87 \%$ \\
\hline 4 & Informan 4 & $26 \%$ & 16 minggu & $0,27 \%$ \\
\hline
\end{tabular}

Keterangan: Asumsi 1 minggu $=6$ hari kerja 
Dari tabel 5 terlihat bahwa bunga pinjaman bank keliling pemburu rente bervariasi dari $0,27 \%$ sampai dengan 2,63\% per hari. Perbedaan tingkat bunga tersebut tampaknya tidak terkait langsung dengan tenor pinjaman. Informan 1, dengan tenor 10 hari, dibebani bunga 2,63\% per hari sedangkan untuk tenor 10 minggu (60 hari) bunganya hanya $0,43 \%$ per hari. Membandingkan tingkat bunga per hari yang dibebankan kepada informan 1 dan informan 4 diperoleh gambaran bahwa tingkat bunga tersebut juga tidak terkait langsung dengan besarnya nominal pinjaman. Apakah tingkat bunga yang dikenakan bank plecit tersebut terkait dengan jenis bank, asal bank atau pasar tempat bank beroperasi; hal itu membutuhkan kajian tersendiri.

\section{Prosedur yang Mudah}

Salah satu kelebihan yang menjadi daya tarik bagi para nasabah bank keliling pemburu rente adalah prosedur yang amat mudah dibandingkan dengan lembaga keuangan formal, misalnya bank umum, BPR, koperasi atau pegadaian. Di bank keliling pemburu rente nasabah cukup menyediakan fotocopy KTP untuk bisa mendapatkan dana pinjaman. Nasabah yang sudah mengangsur cicilan dalam jumlah tertentu bahkan bisa langsung mendapatkan kucuran pinjaman baru tanpa syarat apa pun. Sri Sulastri menceritakannya sebagai berikut.

Iya... (ketika ditawari saya) langsung ambil. (Syaratnya) hanya dengan memberikan foto copy KTP... boleh foto copy KTP saya atau KTP Bapak (suami-red).... (untuk proses pengajuan pinjaman baru) biasanya (sebelum saya selesai mengangsur cicilan) saya disusuki (ditambahi). "Mbah ini (angsuran) tinggal 2 kali, mbok disusuki tooo (Nenek, angsuran cicilan tinggal dua kali. Ditambahi saja ya, Nek...).... Yang harian juga begitu. Kurang 4 atau 5 kali sudah ditambahi lagi. "6

Berdasarkan cerita Sri Sulastri di atas, ia mendapatkan pinjaman dari bank keliling pemburu rente hanya dengan menyerahkan foto copy KTP. Bahkan, ia tidak perlu datang ke bank karena pihak banknyalah yang mendatangi dia di tempat jualannya. Sebelum cicilan pinjaman periode sebelumnya lunas, ia sudah ditawari pinjaman baru dan bisa langsung cair tanpa syarat apa pun. Istilah yang dipakai adalah disusuki. Artinya, apabila cicilan pinjaman sebelumnya tinggal 2 kali dengan besar cicilan

\footnotetext{
${ }^{6}$ Wawancara 15 Juli 2019
} 
Rp10.000; Sri Sulastri bisa langsung ambil pinjaman baru senilai, misalnya, Rp100.000. Satu kali cicilan periode sebelumnya senilai Rp10.000 ditutup dengan pinjaman baru. Sebegitu mudahnya Sri Sulastri mendapatkan dana pinjaman dari bank keliling pemburu rente. Semua kemudahan yang diceritakan oleh Sri Sulastri tersebut juga dialami oleh semua informan lain.

Kemudahan belum selesai sampai di situ. Sutaji mengungkapan, "Kalau misalnya (jualan hari ini) belum laku, ya... libur bayarnya. Besok baru bayar."7 Jadi, menurut Sutaji, apabila hari ini jualannya belum laku dengan demikian ia belum memiliki uang untuk membayar cicilan, ia bisa tidak membayar. Besoknya dia baru membayar cicilan. Sri Sulastri punya cerita lain sekalipun pada prinsipnya sama dengan cerita Sutaji. Ia bisa mencicil cicilan. Kalau cicilan dia seharusnya Rp20.000 sehari; hari ini dia boleh hanya membayar Rp10.000; Rp10.000 sisanya akan dia bayarkan pada hari besoknya.

Cerita tersebut menyingkapkan fakta bahwa dengan fleksibilitas dalam hal pembayaran cicilan, bagi nasabah bank keliling pemburu rente, tenor pinjaman yang secara formal 10 hari praktiknya bisa menjadi 20 hari; 100 hari praktiknya bisa menjadi 200 hari. Apakah fleksibilitas pembayaran angsuran tersebut tidak membuka peluang nasabah ngemplang? Penelitian ini menemukan bahwa semua informan pada dasarnya tidak ada yang memiliki niat untuk tidak membayar cicilan. "Tapi ya kalau satu hari libur, besoknya pasti bayar... kan ya ndak enak misalnya libur (membayar cicilan) sampai dua hari," kata Sutaji. ${ }^{8}$ Sutaji telah menjadi nasabah bank keliling pemburu rente selama lima belasan tahun. Sri Sulastri tidak secara eksplisit memiliki rasa tidak enak tersebut apabila dirinya terlambat membayar cicilan. Dia hanya bercerita bahwa, misalnya cicilan Rp20.000 per hari, ketika ia memang tidak punya uang, cicilan itu bisa diangsur dua kali masing-masing Rp10.000. Akan tetapi, fakta bahwa Sri Sulastri telah menjadi nasabah bank keliling pemburu rente selama dua puluhan tahun menunjukkan dia adalah nasabah yang kredibel.

\section{B. Motif}

Semua informan mahfum bahwa bunga pinjaman yang dibebankan oleh bank keliling pemburu rente amat tinggi, lebih tinggi daripada bank-bank resmi. "Sebenarnya

\footnotetext{
${ }^{7}$ Wawancara 17 Juli 2019

8 Wawancara 17 Juli 2019.
} 
(bunga pinjaman) di BRI ya, ringan...,"9 tutur Suparjo walaupun dia sendiri belum pernah meminjam uang di BRI. Ia mengaku mendengar dari teman-temannya yang mengambil pinjaman di bank. Mereka mengatakan bahwa bunga di bank lebih ringan daripada bunga bank keliling. Hal yang sama diungkapkan oleh Sri Sulastri. Dia pernah menjadi nasabah bank BRI dan BTPN. Ketika itu BRI dan BTPN memberikan kredit berkelompok, satu kelompok terdiri dari 10 orang. "(Bunga kredit) BRI waktu itu 2\% kalau BTPN 3 atau 5\%," jelasnya. ${ }^{10}$ Pertanyaannya, mengapa mereka tetap memilih bank plecit sebagai alternatif permodalan?

Penelitian ini menemukan bahwa tidak ada faktor tunggal yang menjadi alasan para pedagang pasar memilih bank keliling pemburu rente sebagai alternatif permodalan. Terpepet entah karena ada kebutuhan besar (misalnya membiayai anak kuliah) atau barang dagangan mulai menyusut sementara modal tidak punya adalah salah satu alasan. Akan tetapi, alasan ini hanya bisa dipahami dalam konteks pedagang pasar dengan modal dan penjualan kecil, seperti Suparjo. Sebagai pedagang pisang di lapak Pasar Karangayu, nilai barang dagangan Suparjo sekitar Rp1 juta. Apabila pisang dagangannya terjual habis (umumnya terjual habis dalam sehari) Suparjo mendapat untung bersih Rp50-Rp60 ribu (5\%-6\%). Bisa dipahami apabila tiba-tiba anak Suparjo harus membayar kuliah, dia terpepet meminjam uang di bank keliling. Suparjo juga meminjam uang di bank keliling apabila barang dagangannya mulai menyusut dan dia tidak punya uang untuk mengembalikan volume barang dagangannya. Dalam kondisi seperti itu, ia terpepet mengambil pinjaman di bank plecit.

Akan tetapi, alasan terpepet sebagaimana yang dialami Suparjo tampaknya tidak berlaku untuk konteks Rustini, seorang pedagang kue kering di kios relokasi Pasar Johar di Jl. Soekarno-Hatta, Semarang. Dulu ia berjualan di kios milik pribadi di Pasar Johar sebelum pasar itu terbakar tahun 2015 silam. Sekalipun dia tidak mau mengaku berapa nilai barang dagangan yang ada di kiosnya saat ini, melihat dagangan yang memenuhi kiosnya yang kira-kira berukuran 3x4 meter, mudah ditebak bahwa sebagai pedagang, Rustini jauh lebih besar daripada Suparjo. Dia bercerita sebagai berikut.

Dulu saya berjualan di Pasar Johar. Di sana ramai. Penjualan sehari bisa 5-6 juta. Kalau di sini sepi. (Penjualan) ya tinggal separonya. ... Untung

\footnotetext{
${ }^{9}$ Wawancara 15 Juli 2019

${ }^{10}$ Wawancara 15 Juli 2019
} 
ndak gede-gede. Kalau untungnya gede-gede nanti nggak ada yang beli (terkekeh). ... Ya, 30-40. Tiga puluh persen lah. ${ }^{11}$

Omzet penjualan Rustini saat ini sekitar Rp2,5 - Rp3 juta per hari. Bila margin keuntungan yang diambil Rustini 30\%, artinya dia mendapat untung Rp750.000 Rp900.000 per hari. Pendapatan ini amat jomplang dibanding dengan Suparjo yang berpendapatan Rp50.000-Rp60.000 per hari. Begitupun, Rustini juga meminjam uang di bank keliling. Akan tetapi, ia meminjam uang untuk menambah barang, misalnya menjelang Lebaran. Alasan yang sama juga dikemukakan oleh Sutaji, seorang pedagang alat-alat dapur dan pertanian seperti pisau, golok, cangkul, sabit, dsb di Pasar Peterongan, Semarang. Sutaji mengaku bahwa penjualan rata-rata per hari Rp500.000. Dari penjualan sebesar Rp500.000 per hari tersebut, ia mengaku mendapatkan untung bisa sampai 50\%. Itu berarti bahwa pendapatan Sutaji rata-rata Rp250.000 per hari. Dia bercerita, "Dari penjualan 500 ribu; tiga ratus ribunya saya belikan barang lagi; 200-nya untuk kebutuhan rumah.” Sutaji juga meminjam uang di bank keliling untuk melengkapi barang dagangan. Pinjaman itu biasanya dia ambil menjelang Lebaran seperti yang dilakukan Rustini.

Dalam konteks tertentu, terpepet adalah salah satu alasan pedagang pasar mengambil pinjaman di bank keliling. Ia bisa menjadi salah satu alasan, tetapi bukan satu-satunya alasan. Yang menarik adalah, baik pedagang kecil seperti Suparjo maupun pedagang besar seperti Rustini, sama-sama mengaku bahwa mereka meminjam uang di bank plecit karena tidak ada syarat jaminan. Hal ini merupakan alasan lain mengapa para pedagang pasar memilih bank keliling pemburu rente sebagai alternatif permodalan.

Pedagang kecil seperti Suparjo bisa jadi memang tidak memiliki barang yang laku dijaminkan di bank. Tetapi, Rustini mestinya punya. Di Pasar Johar lama dia mengaku pernah meminjam uang di Bank Danamon dan Bank Mandiri dan itu menggunakan jaminan. Ketika itu, pihak bank datang ke pasar menawari pinjaman. Secara rasional, pedagang seperti Rustini seharusnya memilih alternatif permodalan atau pembiayaan resmi, seperti bank resmi atau pegadaian daripada bank keliling pemburu rente karena bunganya yang jauh lebih rendah. Mengapa ia tetap memakai bank keliling pemburu rente sebagai alternatif permodalan? Teori perilaku ekonomi manakah yang menjelaskan fenomena ini? Penelitian ini belum menggali sampai sejauh itu.

\footnotetext{
${ }^{11}$ Wawancara 20 Juli 2019
} 
Proses yang amat mudah sebagaimana telah diulas di atas merupakan alasan lain mengapa para pedagang pasar tersebut memilih bank plecit sebagai alternatif permodalan.

Yang menarik adalah, bahkan dalam hal hutang, ewuh pakewuh dan harga diri pun ikut berperan. Seorang informan bercerita seperti berikut ini.

"Saya pikir daripada pinjam saudara atau tetangga, kalau pinjam mereka, pada saatnya bayar tidak bayar kan bisa jadi bahan cerita. Kalau ini kan yang tahu hanya saya dan salesnya atau banknya. Saya pernah pinjam tetangga... malah jadi bahan cerita (tertawa kecil). Pinjam gak seberapa, jadi omongan... males. " 12

Berdasarkan paparan informan di atas, selain bank plecit, sebenarnya ada alternatif permodalan lain yang sangat mungkin bunganya jauh lebih rendah daripada bunga bank plecit bahkan sama sekali tanpa bunga, yaitu pinjam saudara atau tetangga. Hal tersebut tidak ia lakukan karena pinjam uang ke tetangga atau saudara memiliki risiko jadi bahan omongan. Informan ini pernah mengalami hal tersebut. Rasa malu atau risih itulah yang mendorongnya memilih pinjam ke bank plecit daripada pinjam ke tetangga. Hal senada juga diungkapkan informan lain. "Apalagi kalau misalnya pinjam ke tetangga, mengembalikannya kan juga harus sekaligus. Misale saya hutang 1 juta, lalu saya kembalikan dulu 500, orangnya juga pasti akan marah. Utang sejuta kok dicicil... (menirukan orang mengomel)," kata informan lain.

Jadi, ternyata, perilaku ekonomi (economy behaviour) tidak selamanya didasarkan pada pertimbangan rasional matematis. Rasa malu dan khawatir menjadi bahan omongan menjadi motif utama mereka tidak meminjam pada tetangga atau saudara. Apakah benar bahwa bila mereka "ngemplang" ke bank plecit, pihak bank (melalui debt collector) tidak marah-marah? Tentu saja pihak bank (debt collecor) akan bertindak tegas terhadap mereka. Apakah benar bahwa dengan berhutang di bank keliling orang tidak tahu bahwa mereka punya hutang? Bagaimana mungkin orang tidak tahu bahwa mereka punya hutang apabila setiap hari ada penagih hutang datang menagih cicilan? Dengan demikian, rasa malu dan khawatir menjadi bahan omongan sehingga mereka tidak meminjam uang kepada tetangga atau saudara masih perlu didalami lebih lanjut. Atau

\footnotetext{
12 Wawancara tanggal 15 Juli 2019
} 
sesungguhnya para pedagang tersebut beranggapan bahwa hutang adalah tabu sehingga mereka malu meminjam kepada tetangga atau saudara?

Terkait dengan alasan mereka lebih suka meminjam di bank pemburu rente daripada kepada tetangga atau saudara karena rasa malu dan khawatir menjadi bahan omongan di atas, yang menarik adalah bahwa semua informan mengaku tidak mau apabila diperlakukan kasar oleh debt collector apabila mereka, misalnya, terlambat mengangsur cicilan. "Tapi kalau orangnya galak, belakangnya saya nggak akan ambil. Saya lihat itu, kalau saya prei dia ngomel-ngomel, nanti pasti saya berhentikan," kata Sutaji. ${ }^{13} \mathrm{Hal}$ itu menimbulkan pertanyaan: apakah karena begitu banyaknya pemain bank keliling dan nasabah benar-benar memiliki banyak pilihan sehingga mereka tidak mau diperlakukan kasar oleh bank keliling pemburu rente? Ataukah hal tersebut merupakan indikasi bahwa dalam kasus utang piutang antara pedagang pasar sebagai nasabah dan bank plecit sebagai kreditor terjadi jalin-menjalin secara operasional antara ekonomi modern yang menekankan displin administratif, pembedaan secara tegas antara hak dan kewajiban di satu sisi dan ekonomi tradisional Jawa yang bercorak kebersamaan, tepo seliro di sisi lain? Hal ini juga memerlukan kajian lebih lanjut.

\section{Penggunaan Dana}

Awalnya itu kan anu... (berpikir sejenak). Anu... apa itu... saya ini kepepet (dengan tempo cepat dan intonasi tinggi). Jadi, waktu itu saya kepepet... mau bayar anak sekolah, tapi tidak punya uang. Lalu ada tawaran pinjaman ini dari koperasi saya ambil. Jadi, dari pinjaman, sebagian dipakai untuk bayar anak sekolah, sebagian dipakai untuk tambah modal (dengan nada rileks). Dagangan sudah semakin sedikit, kalau tidak ditambahi kan bagaimana? ${ }^{14}$

Berdasarkan cerita di atas, menurut informan, dia meminjam uang di bank sebagian dipakai untuk membayar sekolah anaknya. Ia mengaku terpepet maka meminjam uang di bank plecit. Selain untuk membayar uang sekolah anaknya, sebagian uang pinjaman dari bank plecit tersebut dipakainya untuk menambah barang dagangan, hanya untuk menjaga agar barang dagangan tidak menipis, bukan untuk mengembangkan usaha. Yang jelas, informan berhutang bukan untuk konsumsi. Alasan serupa peneliti temukan pada semua informan lain. Semua informan meminjam uang di

\footnotetext{
${ }^{13}$ Wawancara 17 Juli 2019

14 Wawancara 16 Juli 2019
} 
bank keliling bukan untuk konsumsi. Menariknya, pada dua informan dengan skala dagang kecil; hutang tidak pernah dipakainya untuk membesarkan usaha; sedangkan pada dua informan lain yang memiliki skala usaha lebih besar, pada waktu tertentu mereka berhutang untuk menambah barang dagangan atau membesarkan skala usaha. “... biasanya menjelang Lebaran itu biasanya (hutang) ditambah untuk nambah modal." ${ }^{15}$ Apakah meminjam uang di bank keliling untuk mengembangkan skala usaha semata-mata terkait dengan besar-kecilnya usaha yang ada sekarang atau sekaligus juga terkait dengan kemampuan manajerial dan kewirausahaan pedagang pasar; penelitian ini juga belum mengungkap sampai ke sana.

Selain tidak berhutang untuk konsumsi, semua informan pada dasarnya bisa mengukur kemampuan bayarnya. Semua informan mengaku bahwa mereka akan meminjam hanya apabila butuh walaupun ditawari oleh pihak bank plecit. Selain itu, untuk menentukan besarnya pinjaman, mereka juga mengukur dengan kemampuan bayar mereka.

\section{Involusi Usaha}

Warung tenda itu terletak di Jl. Sompok Lama, persis di pojok kanan depan SMP Negeri 37, tepatnya di tikungan tepat di samping pemakaman umum Sompok. Ukurannya sekitar $3 \times 4$ meter. Selain menyediakan minuman seperti kopi, teh, dan minuman-minuman sachetan, juga tersedia pisang goreng, tempe goreng. Sebuah kotak kayu berukuran sekira panjang $25 \mathrm{~cm}$, lebar $50 \mathrm{~cm}$ dan tinggi $30 \mathrm{~cm}$ terletak di atas meja. Bagian depan kotak kayu tersebut berdinding kaca sehingga para pembeli bisa memilih lauk yang dipajang di kotak tersebut. Ada beberapa potong ayam goreng yang diletakkan di atas sebuah piring, telor dadar. Di tempat itulah Sri Sulastri berjualan. Ukuran dan skala usahanya sebegitu-begitu saja, setidak-tidaknya sejak 5 tahun terakhir.

Tidak ditemukan informasi bahwa berhutang di bank keliling pemburu rente menyebabkan para pedagang pasar bangkrut sekalipun semua informan mengakui bunga yang ditetapkan bank tersebut sangat tinggi. Bagi Suparjo, bahkan, pinjaman bank keliling itu telah membantunya menguliahkan kedua anaknya; yang sulung sudah lulus dari Jurusan Akuntansi sedangkan yang bungsu tahun ini diharapkan lulus dari Akademi Kebidanan. Satu-satunya informasi mengenai pedagang bangkrut karena terlilit hutang bank plecit datang dari Sutaji. Ia mengaku melihat beberapa pedagang

\footnotetext{
${ }^{15}$ Wawancara 17 Juli 2019
} 
mengalami kebangkrutan. "Tetapi itu pasti salah orangnya. Pinjamannya disalahgunakan. Untuk membeli baju, untuk membeli makan, atau ambilnya terlalu banyak. Itu yang bikin bangkrut," kata informan. ${ }^{16}$

Jadi, menurut Sutaji, bukan soal bunga yang terlampau tinggi yang menyebabkan seorang pedagang pasar peminjam hutang bank plecit bangkrut, melainkan kesalahan pedagang menggunakan hutang tersebut, yaitu untuk konsumsi. Apa yang dikemukakan Sutaji bahwa bunga yang tinggi masih bisa tertutup oleh laba usaha diperkuat dengan perhitungan matematis di bawah ini.

Tabel 6.

Selisih Bunga antara Laba Usaha/Hari dengan Beban Bunga/Hari

\begin{tabular}{|l|l|l|l|l|}
\hline Informan & $\begin{array}{l}\text { Gambaran Kasar Perputaran } \\
\text { Usaha/hari }\end{array}$ & Laba Usaha/hari & $\begin{array}{l}\text { Beban } \\
\text { bunga } \\
\text { /hari }\end{array}$ & $\begin{array}{l}\text { Selisih } \\
\text { laba } \\
\text { bunga }\end{array}$ \\
\hline 1 & $\begin{array}{l}\text { Modal untuk makanan: 200.000 } \\
\text { Modal utk minuman: 45.000 } \\
\text { Total modal/hari maks: 245.000 } \\
\text { Pengeluaran minimal: 60.000 utk } \\
\text { cicilan utang. (informasi } \\
\text { pengeluaran lain tidak tersedia). }\end{array}$ & $\begin{array}{l}\text { Minimal: } \\
(60.000: 245.000) \times 10 \\
0 \% . \\
=24,49 \%\end{array}$ & $22,96 \%$ \\
\hline 2 & $\begin{array}{l}\text { Modal: Rp1.000.000/hari } \\
\text { Keuntungan: Rp60.000/hari }\end{array}$ & $6 \%$ & 0,31 & $5,69 \%$ \\
\hline 3 & $\begin{array}{l}\text { Secara eksplisit menyebut, } \\
\text { keuntungannya 40-50\% }\end{array}$ & $40 \%$ & $0,61 \%$ & $39,39 \%$ \\
\hline 4 & $\begin{array}{l}\text { Secara eksplisit menyebut } \\
\text { keuntungan 30\%-40\% }\end{array}$ & $30 \%$ & $0,27 \%$ & $29,73 \%$ \\
\hline
\end{tabular}

Tabel di atas menunjukkan bahwa selisih antara margin laba per hari para pedagang pasar pengguna jasa bank plecit dengan beban bunga dari bank plecit semua positif. Dengan demikian bisa diambil kesimpulan bahwa secara empiris dan teoretis tidak ada fakta yang menunjukkan bahwa bunga bank plecit yang amat tinggi merugikan pedagang. Tentu saja, bunga pinjaman — sekecil apa pun apalagi sangat tinggi-akan mengurangi margin keuntungan pedagang. Dalam kasus ini, satu-satunya asumsi yang bisa kita gunakan untuk mengatakan bahwa bunga bank plecit merugikan pedagang adalah apabila barang dagangan tidak laku. Ketika barang dagangan tidak laku, dengan sendirinya bunga pinjaman menjadi beban. Akan tetapi, sesungguhnya beban ini juga berlaku seandainya para pedagang menggunakan sumber-sumber

\footnotetext{
${ }^{16}$ Wawancara 17 Juli 2019
} 
pembiayaan lain yang menerapkan bunga. Simulasinya terlihat dalam tabel 7 di bawah ini.

Tabel 7.

Simulasi Perhitungan Apabila Penjualan = 0

\begin{tabular}{|l|l|l|l|l|l|}
\hline Penjualan/hari & $\begin{array}{l}\text { Margin } \\
\text { Laba }\end{array}$ & $\begin{array}{l}\text { Nominal } \\
\text { Laba }\end{array}$ & $\begin{array}{l}\text { Bunga } \\
\text { Bank/ hari }\end{array}$ & $\begin{array}{l}\text { Nominal } \\
\text { Cicilan } \\
\text { Bunga }\end{array}$ & $\begin{array}{l}\text { Selisih } \\
\text { nominal dan } \\
\text { cicilan dan } \\
\text { nominal laba }\end{array}$ \\
\hline 2.000 .000 & $30 \%$ & 600.000 & $0,27 \%$ & 5.400 & $594.600,00$ \\
\hline 0 & $30 \%$ & 0 & $0,27 \%$ & 5.400 & $-5.400,00$ \\
\hline
\end{tabular}

Keterangan: Tabel simulasi perhitungan di atas diambil berdasarkan informasi dari informan 4. Dia meminjam uang di bank keliling sebesar Rp2.000.000 dengan bunga 0,27\% per hari (lihat tabel 5). Ketika penjualan mencapai 2.000 .000 sehari; bunga bank sebesar $0,27 \%$ tertutup oleh margin laba (selisih positif). Tetapi, ketika penjualan 0 (tidak laku sama sekali), bunga bank sebesar $0,27 \%$ tersebut menjadi beban bagi informan (selisih negatif). Selisih margin laba dan bunga pinjaman akan menjadi positif atau negatif, tergantung pada laku-tidaknya barang dagangan. Dari simulasi tersebut jelaslah bahwa misalnya seorang pedagang bangkrut atau mengalami involusi usaha, hal tersebut terjadi bukan pertama-tama karena faktor bunga pinjaman yang tinggi melainkan lebih karena barang dagangannya tidak laku.

Dengan kata lain, dalam kondisi terpepet, tidak punya agunan atau tidak punya waktu untuk mengajukan pinjaman ke bank resmi, dengan proses yang amat mudah, pembayaran yang fleksibel, dan keengganan untuk meminjam tetangga atau saudara; toh margin penjualan masih bisa menutupi bunga yang harus dibayar; bagi pedagang pasar menggunakan dana pinjaman bank plecit adalah pilihan pembiayaan yang rasional sekalipun diketahui bunganya tinggi!

\section{E. Siapa Menghidupi Siapa}

Yang lebih menarik dari penelitian ini sesungguhnya adalah relasi ekonomi antara pedagang pasar sebagai nasabah dan pihak bank sebagai pemilik modal. Pihak bank begitu memanjakan nasabah dengan berbagai kemudahan yang tidak diberikan oleh bank-bank formal. Tanpa penelitian sekalipun bisa ditebak bahwa pihak bank begitu memanjakan nasabah (para pedagang pasar pemakai jasa bank plecit) karena para pedagang pasar tersebut menguntungkan! Tanpa alasan ini, tidak mungkin pihak bank melayani mereka. Para pedagang tersebut menguntungkan tidak hanya dalam arti 
memberikan selisih bunga bagi bank keliling, tetapi juga kredibilitas mereka sebagai nasabah: Sri Sulastri dua puluhan tahun menjadi nasabah bank keliling, Suparjo delapan tahun dan Sutaji lima belasan tahun.

Benar bahwa para pedagang pasar, terutama pedagang kecil, sangat terbantu dengan adanya pinjaman dari bank keliling pemburu rente. Terbukti bahwa karena pinjaman bank, seorang informan bisa menyekolahkan kedua anaknya hingga lulus perguruan tinggi. Informan lain tetap bisa berdagang dengan memutar pinjaman bank tersebut. Pertanyaannya, apakah bank keliling pemburu rente bisa tetap hidup tanpa "pertolongan" para pedagang pasar?

Hubungan ekonomi antara bank keliling pemburu rente sebagai pemilik modal dan para pedagang pasar sebagai nasabah bukan hubungan pemilik modal dan buruh atau majikan dan pekerja. Hubungan ekonomi tersebut seharusnya adalah partnership yang bersifat salingketergantungan (interdependensi). Masalahnya, apakah hubungan saling-ketergantungan itu tercermin dalam pembagian laba? Bagaimana bank keliling pemburu rente bisa menetapkan bunga harian berkisar 0,2 s.d. 6,2\%? Ataukah besaran bunga tersebut memang tarif bunga yang paling rasional?

Apa yang terjadi pada Sri Sulastri menarik untuk dicermati. Dua puluhan tahun dia menjadi nasabah bank keliling pemburu rente. Selama itu dia menjadi nasabah dan masih dipercaya untuk diberi hutang oleh bank membuktikan bahwa dia adalah nasabah yang kredibel. Berapa 'keuntungan' yang telah ia berikan kepada bank keliling selama dua puluhan tahun tersebut? Di sisi lain, sekalipun diberi hutang oleh bank keliling, usahanya sendiri tidak mengalami perkembangan berarti. Tidak berlebihan apabila dikatakan bahwa bunga tinggi dari bank keliling pemburu rente terpaksa dia tanggung sekadar untuk bertahan hidup. Ibarat orang berjalan, usaha Sri Sulastri seperti orang berjalan di atas treadmill. Bisa jadi dia berkeringat atau ngos-ngosan seolah-olah telah berjalan sekian kilometer; tapi pada dasarnya dia hanya berada di situ-situ juga, tidak bergeser sejengkal pun. Di sisi lain, menurut pengakuan Eko, salah seorang salesman dan debt collector sebuah bank keliling pemburu rente, bank tempatnya bekerja kini telah memiliki 38 cabang hanya di Jawa Tengah. Realitas Sri Sulastri di satu sisi dan bank tempat Eko bekerja di sisi lain memunculkan sebuah pertanyaan: siapa menghidupi siapa. Penelitian lebih lanjut diperlukan untuk menjawab pertanyaan ini. 


\section{Simpulan dan Keterbatasan}

Berdasarkan uraian di atas bisa disimpulkan bahwa pertama, pilihan para pedagang pasar menggunakan jasa bank keliling pemburu rente atau bank plecit dalam konteks situasi dan kondisi yang mereka hadapi adalah pilihan yang secara ekonomis rasional. Kedua, tidak ada alasan tunggal yang menjelaskan mengapa para pedagang pasar tersebut tetap memilih bank keliling pemburu rente sebagai alternatif permodalan sekalipun mereka menyadari bahwa tingkat bunga yang ditetapkan sangat tinggi. Terpepet atau tanpa jaminan, sebagai contoh, hanyalah salah satu alasan tetapi bukan satu-satunya alasan. Ketiga, sekalipun bunga bank plecit sangat tinggi; tidak ditemukan fakta dan informasi empiris bahwa bunga bank plecit yang dinilai mencekik tersebut menyebabkan kemerosotan usaha sebagaimana dipersepsikan masyarakat selama ini.

\section{Keterbatasan}

Penelitian ini belum mendalami informasi yang mengungkapkan bahwa para pedagang pasar yang mengalami kebangkrutan karena terlilit hutang bank plecit sesungguhnya adalah akibat dari penyalahgunaan dana oleh pedagang pasar itu sendiri di mana hutang yang seharusnya dipakai untuk hal-hal yang produktif digunakan untuk hal-hal yang konsumtif.

\section{Daftar Pustaka}

Badan Perencanaan Pembangunan Nasional (2009). Peran Sektor Informal sebagai Katup Pengaman Masalah Ketenagakerjaan. Jakarta: Bappenas.

Basri, Faisal (2013). Perekonomian Indonesia: Tantangan dan Harapan bagi Kebangkitan Indonesia. Jakarta: Penerbit Erlangga.

Boediono (2008). Ekonomi Mikro. Yogyakarta: BPFE

Freedman, Maurice (bookreview). Agricultural Involution-The process of Ecological Change in Indonesia. Downloaded rom e-resources perpusnas.go.id, 2 Mei 2019.

Geertz, Clifford (1983). Involusi Pertanian. Jakarta: Bhratara Karya Aksara.

Gilarso, T. (2014). Pengantar Ilmu Ekonomi Mikro. Yogyakarta: Kanisius. (2014). Pengantar Ilmu Ekonomi Makro. Yogyakarta: Kanisius.

Glessne, Corrine (1999). Becoming Qualitative Researchers. New York: Longman. 
Hammar, Lawrence. (1988). The Philosphy of Shared Poverty: rethinking Agricultural Involution and the Culture of Geertz. Journal of Historical Sociology, Vol. 1, 3 September 1988.

Idrus, Muhammad (2007). Metode Penelitian Ilmu-ilmu Sosial. Yogyakarta: UII Press.

Ihalauw, John J.O.I (2004). Bangunan Teori. Salatiga: Satya Wacana University Press.

Kitley, Philip. (1992). Ornamentation and Originality: Involution in Javanese Batik. Journal of Cornell Southeast Asia Program.

Kuncoro Mudrajad (2010). Ekonomika Pembangunan: Masalah, Kebijakan, dan Politik. Jakarta: Penerbit Erlangga.

(2006). Ekonomika Pembangunan: Teori, Masalah, dan Kebijakan. Yogyakarta: UPP STIM YKPN.

Mankiw, Gregory N, dkk (2014). Pengantar Ekonomi Mikro. Jakarta: Penerbit Salemba Empat.

Moleong, Lexy J. (2005). Metodologi Penelitian Kualitatif. Bandung: PT. Remaja Rosdakarya.

Pitoyo, Agus Joko (2007). Dinamika Sektor Informal di Indonesia: Prospek, Perkembangan, dan Kedudukannya dalam Sistem Ekonomi Makro. Jurnal Populasi Vol 18, No 2, 2007.

Pormes, Ludwina (2015). Involusi Usaha Ikan Asar. Semarang: Sarana Pustaka.

Quick, J and S Hall (2015). Part two: Qualitative Research. United Kingdom: The Association for Perioperative Practice.

Salim, Agus (2006). Teori dan Paradigma Penelitian Sosial. Yogyakarta: Tiara Wacana.

Salvatore, Dominick (2013). Mikroekonomi. Jakarta: Penerbit Erlangga.

Suton, Jane and Zubin Austin (2015). Qualitative Research: Data Collection, Analysis, and Management. CJHP Vol. 68 No 3, May-June 2015.

Suwondo, Kutut (2005). Otonomi Daerah dan Perkembangan Civil Society di Aras Lokal. Salatiga: Fakultas Ilmu Sosial dan Politik Universitas Kristen Satya Wacana.

www.asatu.id

www.bps.go.id

www. dispendukcapil.semarangkota.go.id

www.jatengtoday.com

www.Kompasiana.com 
Majalah Ilmiah Solusi

Vol. 17, No. 4 Oktober 2019

ISSN : 1412-5331

www.menara62.com

www.Tribunjogja.com

www.koranmemo.com

www.radarseamarang.com 
Majalah Ilmiah Solusi

Vol. 17, No. 4 Oktober 2019

ISSN : 1412-5331

Halaman ini sengaja dikosongkan 